\title{
Enthesitis: Myth or Reality?
}
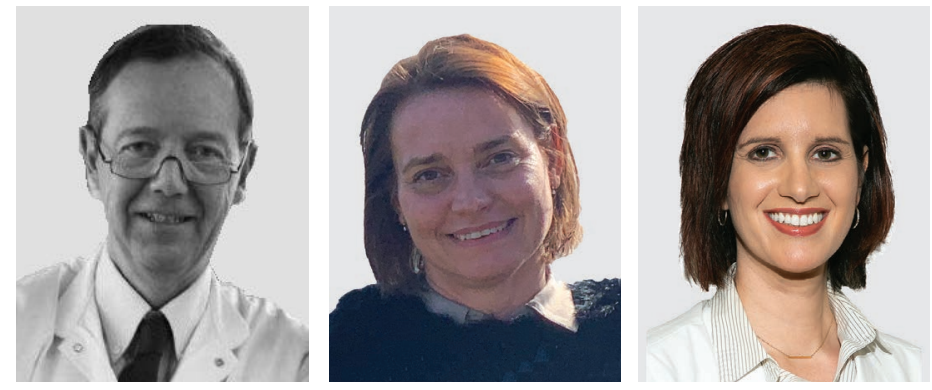

Homer's Iliad tells the epic story of the Trojan War, a 10-year siege of the city of Troy, conducted by an alliance of Greek kings ${ }^{1}$. According to Homer, the reason for the Trojan war was the abduction of the most beautiful of women, Helen, by the Trojan prince Paris. Since the excavation works of the German archeologist Heinrich Schliemann, we know that the city indeed existed on the northwestern coast of Turkey. The Iliad gives an account of only the 10th year of the siege, in which the Greek warrior Achilles slays Hector, the commander of the Trojan army, and drags him for 9 days behind his chariot around the city. According to Greek mythology, Achilles was unbeatable, yet vulnerable for a single spot of his body where his mother held him as a baby while dipping him in the river Styx. Following the death of Hector, Paris shot an arrow guided by the god Apollo at Achilles. The arrow struck Achilles right at the enthesis of the tendon in the heel, presumably leaving him defenseless on the battlefield and leading to his death.

Homer's poems clearly illustrate the mechanical vulnerability of the entheses, although the poet could not be aware of the mechanoinflammatory entheseal concepts 2800 years ago. In their report entitled "Entheseal changes in response to age, body mass index, and physical activity: an ultrasound study in healthy people" ${ }^{2}$, in this issue of The Journal, Sibel Bakirci and colleagues give an accurate account of changes at various entheseal sites in 80 healthy volunteers by the use of B-mode and Doppler ultrasound (US). The investigators' choice to use US as an investigative tool makes sense because US is more sensitive than clinical examination for picking up signs of enthesitis ${ }^{3}$. Thickening of the tendon and enthesophytes were the most frequently observed entheseal changes, found in $86 \%$ and $87 \%$ of healthy volunteers, respectively. These findings appeared to be significantly related to age, high body mass index, male sex, and physical activity level. Although naysayers may criticize the number of volunteers as rather small, and see the cross-sectional design and the absence of an imaging comparator such as magnetic resonance imaging (MRI) as limitations, the results found in healthy persons may affect the way we think about entheseal changes in patients.

How must we see the imaging results of Bakirci and colleagues in a broader context? The Outcome Measures in Rheumatology (OMERACT) US working group (WG) strives to provide a standard of US guidance for use in clinical trials, following a stringent validation process and reflecting the 3 pillars of the OMERACT process, i.e., truth (validity), discrimination (reproducibility and responsiveness), and feasibility, also dubbed as the "filter"4. Recently, the WG published a comprehensive overview of the US validation exercises conducted by the group over the last 15 years 5 . Based on a Delphi consensus across 24 rheumatologists expert in US, the following core set of elementary lesions was included in the definition of enthesitis: hypoechogenicity of the tendon insertion, increased thickness of the tendon insertion, intratendinous calcifications, enthesophytes, bone erosions, and Doppler activity, all within a 2-mm distance of the bone corte $\mathrm{x}^{5,6}$. No agreement was obtained for including bursitis or tendon Doppler activity away from the enthesis in the definition of enthesitis. A subsequent intra- and interreliability exercise using the agreed US definition demonstrated US to be a reliable outcome measure instrument for detecting enthesophytes and Doppler activity in patients with spondyloarthritis $(\mathrm{SpA})^{6}$. Reconciling the US definition of enthesitis with the filter, we - being 3 busy clinical practicing rheumatologists - commend the OMERACT US score for feasibility and discrimination. Yet, how does it perform in terms of criterion validity? Criterion validity assesses the degree to which the scores of an instrument are an adequate reflection of the gold standard. The " $2-\mathrm{mm}$ enthesitis" concept stands in sharp contrast with a previous concept put forward by Benjamin and McGonagle, in which they consider the entheses of the human body as an organ? In the entheses organ concept, the enthesis proper, along with the various fibrocartilages, bursa, fat pad, the trabecular bone, and even the adjacent fascia, collectively constitute the enthesis organ. From clinical practice, we know that

See Enthesis in healthy people, page 968

Personal non-commercial use only. The Journal of Rheumatology Copyright $(\subset) 2020$. All rights reserved. 
patients with SpA presenting with heel enthesitis frequently have involvement of the tendon and retrocalcaneal bursa. MRI findings also corroborate this view ${ }^{8}$. Compared to the clinical picture, the 2-mm US enthesis looks bare.

The report of Dr. Bakirci raises the question whether there exists a sharp line between physiologically occurring changes at the entheses developing in normal life versus SpA lesions. Bone erosions and Doppler activity may be the exceptions, although this is far from clear. Remarkably, Dr. Bakirci does not mention the occurrence of bursitis or tendonitis. Does this mean these abnormalities were not found in healthy volunteers or was it simply ignored by the investigators? This would be interesting to know because bursitis and tendonitis were specifically left out of the final OMERACT US definition of enthesitis. Recently, Tom, et al compared a cohort of 50 healthy persons versus 50 patients with psoriatic arthritis (PsA). Bursitis and calcifications did not contribute to distinguishing the 2 groups from each other".

So the question remains: do we really know what the enthesis represents? As more and more studies are appearing studying entheseal changes in both healthy persons and patients with SpA, our knowledge of the character and behavior of the enthesis organ in health and disease is increasing rapidly. The innate immune system has been implicated as the main driver of enthesitis, involving multiple immune cells and cytokines including type 3 innate lymphoid cells, $\gamma \delta$ T cells, myeloid cells, mesenchymal stem cells, interleukin (IL)-17A, IL-23, tumor necrosis factor- $\alpha$, and prostaglandin E. Further, differences in the entheseal anatomy of the spine and periphery have been described, along with variance in immunologic involvement in these sites ${ }^{10}$. Over the last several years, more understanding of the involvement of the nail entheses in psoriasis and PsA has come to light, along with a proposed sonographic index for nail entheses ${ }^{11}$. The enthesis may turn out to be a widely heterogeneous organ, hybridly responding to stimuli in health or to mechanoinflammatory stimuli in various diseases.

The enthesis is a complex and fascinating feature of SpA that straddles a watershed in history. As to future imaging scores, some questions have to be addressed: because many lesions are found in healthy subjects, does it make sense to include them in an inflammatory enthesitis score? Secondly, taking into account the hybrid character of the enthesis in health and disease, which anatomic sites need to be included in a future scoring system for enthesitis? And third, how do we best incorporate an enthesitis scoring system into daily practice? As our insights are evolving, we may have to return to the drawing table.
GEORGE BRUYN, MD, PhD,

MC Groep Hospitals,

Lelystad, the Netherlands;

PETRA HÁNOVÁ, MD, $\mathrm{PhD}$,

Revmatologicky Ustav,

Prague, Czech Republic;

NATALIE FAITH, MD, RhMSUS, RMSK,

Florida Medical Clinic,

Rheumatology,

Zephyrhills, Florida, USA.

Address correspondence to Dr. G. Bruyn, MC Groep Hospitals, Department of Rheumatology, Lelystad 8333 AA, the Netherlands. E-mail: gawbruyn@wxs.nl

\section{REFERENCES}

1. Homer. The Iliad, trans. A. Verity. Oxford: Oxford University Press; 2012.

2. Bakirci S, Solmaz D, Stephenson W, Eder L, Roth J, Aydin SZ. Entheseal changes in response to age, body mass index, and physical activity: an ultrasound study in healthy people. J Rheumatol 2020;47:968-75.

3. Balint P, Kane D, Wilson H, McInnes IB, Sturrock RD. Ultrasonography of entheseal insertions in the lower limb in spondyloarthropathy. Ann Rheum Dis 2002;61:905-10.

4. Boers M, Brooks P, Strand V, Tugwell P. The OMERACT filter for outcome measures in rheumatology. J Rheumatol 1998;25:198-9.

5. Bruyn GA, Iagnocco A, Naredo E, Balint PV, Gutierrez M, Hammer HB, et al; for the OMERACT Ultrasound Working Group. OMERACT definitions for ultrasonographic pathologies and elementary lesions of rheumatic disorders 15 years on. J Rheumatol 2019;46:1388-93.

6. Balint PV, Terslev L, Aegerter P, Bruyn GAW, Chary-Valckenaere I, Gandjbakhch F, et al; on behalf of the OMERACT Ultrasound Task Force members. Reliability of a consensus-based ultrasound definition and scoring for enthesitis in spondyloarthritis and psoriatic arthritis: an OMERACT US initiative. Ann Rheum Dis 2018;77:1730-5.

7. Benjamin M, McGonagle D. The enthesis organ concept and its relevance to the spondyloarthropathies. Adv Exp Med Biol 2009;649:57-70.

8. Eshed I, Bollow M, McGonagle D, Tan AL, Althoff CE, Asbach $\mathrm{P}$, et al. MRI of enthesitis of the appendicular skeleton in spondyloarthritis. Ann Rheum Dis 2007;66:1553-9.

9. Tom S, Zhong Y, Cook R, Aydin S, Kaeley G, Eder L. Development of a preliminary ultrasonographic enthesitis score in psoriatic arthritis - GRAPPA Ultrasound Working Group. J Rheumatol 2019;46:384-90.

10. McGonagle DG, McInnes IB, Moots R. The role of IL-17-A in axial spondyloarthritis and psoriatic arthritis: recent advances and controversies. Ann Rheum Dis 2019;78:1167-78.

11. Cunha JS, Qureshi AA, Reginato AM. Nail enthesis ultrasound in psoriasis and psoriatic arthritis: a report from the 2016 GRAPPA annual meeting. J Rheumatol 2017;44:688-90.

J Rheumatol 2020;47:945-6; doi:10.3899/jrheum.200114 


\section{Correction}

Enthesitis: Myth or Reality?

Bruyn G, Hánová P, Faith N. Enthesitis: myth or reality? [editorial] J Rheumatol 2020;47:945-6. The order of the authors' names in this editorial should be Petra Hánová, Natalie Faith, George A. Bruyn.

doi:10.3899/jrheum.200114.C1 